\title{
KETERLIBATAN ORANG TUA DALAM PELAKSANAAN PENDIDIKAN AGAMA ISLAM DALAM RUMAH TANGGA DI DESA TAMBANGAN, KECAMATAN KAJANG, KABUPATEN BULUKUMBA
}

\author{
Oleh: Chaeruddin B.
}

\begin{abstract}
The research conducted in Tambangan village of Kajang district was directed to gain objective description on household base involvement of parents towards Islamic education administration. The data collection was done under the intensive observation and interview to all respondents. The result of this research showed that: Most of parents didn't do direct involvement in Islamic education administration in their family. They delegated that self involvement to the teachers of religion subjects in the school and/or institute for Qur'anic education (TPA)/Qur'anic kindergarten (TKA) in stead. The parents who took direct involvement in Islamic education administration apply habit formation, giving advice, noble characters methods in terms of Islamic orders and prohibition. They also used traditional approach and method (Al-Bagdadi) particularly applied in Quranic writing and recitation education.
\end{abstract}

KEYWORDS: Islamic Religion Education, Parents, Family/household.

LINGKUNGAN rumah tangga adalah lingkungan yang paling awal dikenal oleh anak. Dalam lingkungan inilah anak pertama-tama menerima pendidikan dari kedua orang tuanya. Dengan begitu orang tua merupakan pendidik utama dan pertama bagi anak-anak mereka. Bentuk pertama dari pendidikan terdapat dalam kehidupan keluarga. Di dalam keluarga, orang tualah yang menjadi kepala keluarga. Pangkal ketentraman dan kedamaian hidup terletak dalam keluarga. Mengingat pentingnya hidup keluarga yang demikian itu, maka Islam memandang keluarga bukan hanya sebagai persekutuan kecil saja, tetapi lebih dari itu yakni sebagai lembaga hidup manusia yang dapat memberi kemungkinan celaka dan bahagianya anggota-anggota keluarga tersebut di dunia dan akhirat.

*Magister dalam bidang Pendidikan dan Keguruan UIN Alauddin Makassar. Saat ini sebagai dosen Fakultas Tarbiyah dan Keguruan UIN Alauddin pengampu mata kuliah Metodologi Pengajaran PAI, Etika Profesi Keguruan dan sebagai Auditor Mutu Akademik Internal (AMAI) 
Setiap anak yang lahir akan melalui proses pengasuhan dari orang tua dalam lingkungan rumah tangga, minimal dalam jangka waktu tertentu. Sangat langka ditemukan anak lahir langsung berada dalam asuhan orang lain.

Bertolak dari kenyataan tersebut, maka lingkungan rumah tangga perlu dikondisikan sesuai dengan tuntunan ajaran Islam, karena lingkungan ini sangat berpengaruh terhadap pembentukan kepribadian anak. Rasulullah saw. Bersabda:

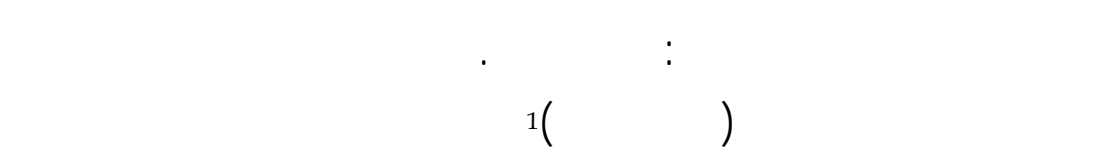

Dari Abu Hurairah r.a. berkata: Nabi saw bersabda: Tiap-tiap anak dilahirkan dalam keadaan fithrah (Islam), maka orang tuanyalah yang menjadikan ia Yahudi, Nashrani atau Majusi. (HR. Bukhari).

Hadis di atas menunjukkan bahwa tanggung jawab pendidikan secara mendasar terpikul di atas pundak orang tua. Sejalan dengan hal tersebut, adalah firman Allah dalam Q.S. al-Tahriim/66:6, sebagai berikut:

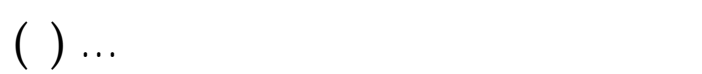

Hai orang-orang yang beriman, peliharalah dirimu dan keluargamu dari api neraka... ${ }^{2}$

Dari ayat ini dapat dipahami bahwa tanggung jawab pendidikan terutama pendidikan Islam bagi anak merupakan kewajiban bagi orang tua dan amanah dari Allah swt. Mengacu kepada pemahaman di atas, tugas pendidikan tidak dapat dilimpahkan sepenuhnya kepada pihak lain, termasuk juga pada sekolah, karena lembaga pendidikan tersebut diadakan untuk membantu dalam arti memudahkan usaha orang tua dalam mengantarkan anak-anaknya memasuki masyarakat yang kompleks sebagai orang dewasa. Tanggung jawab utama dalam mempersiapkan anakanak agar mampu berdiri sendiri, sepenuhnya berada di tangan orang tua sebagai pendidik kodrati.

Dalam lingkungan rumah tangga, orang tua selaku pendidik harus dapat menjalankan tugas dan kewajibannya dengan baik dan benar, terutama dalam menanamkan dan mengembangkan keimanan dan keIslaman anak, agar tantangan pendidikan agama Islam dari luar rumah tangga dapat teratasi dengan sebaik-baiknya. Tanggung jawab dan kewajiban orang tua terhadap pendidikan anak menurut Abdullah Nashih Ulwan yaitu, sebagai berikut: 
1. Membina anak untuk beriman kepada Allah dengan jalan merenungkan dan memikirkan ciptaan bumi dan langit secara bertahap dari penginderaan kepada akal, dari yang parsial menuju ke yang bersifat integral, dari yang sederhana ke yang semakin kompleks, sehingga dapat memperkokoh iman.

2. Menanamkan dalam jiwanya ruh kekhusyukan, ketakwaan dan ibadah kepada Allah. Memperdalam takwa melalui latihan salat pada usia tamyiz dengan tekun melatih bertingkah laku dengan rasa haru dan menangis di saat mendengar suara bacaan Alquran.

3. Menanamkan perasaan selalu ingat kepada Allah di setiap kegiatan dan situasi. Melatih bahwa Allah selalu mengawasi, melihat dan mengetahui segala rahasia. Jelasnya orang tua menunjukkan kepada anak dengan amal, pikiran dan perasaan, dan melatihnya melalui pengajaran keikhlasan kepada Allah dalam perkataan, perbuatan, dan seluruh aktivitas hidupnya. ${ }^{3}$

Uraian di atas menunjukkan betapa besar tanggung jawab orang tua, di sisi lain diakui pula bahwa orang tua mempunyai pengaruh yang sangat besar terhadap kepribadian anak.

Semua agama mengenal kewajiban mendidik anak, meskipun sebagian terbatas dengan kewajiban pembinaan moral atau akhlak saja. Agama Islam mewajibkan pemeluknya terutama orang tua untuk mendidik anaknya atau generasi muda, agar dapat hidup lebih sejahtera di dunia ini dan di akhirat nanti. ${ }^{4}$

Bertolak dari uraian di atas dapat dipahami bahwa orang tua dituntut untuk terlibat langsung dalam mendidik anak-anak mereka di lingkungan keluarga, karena terdapat beberapa aspek dari pendidikan agama Islam dalam lingkungan keluarga tidak dapat diserahkan ke sekolah, pesantren, dan ke lembaga-lembaga pendidikan lainnya.

Undang-undang Republik Indonesia No. 20 Tahun 2003 tentang SISDIKNAS bab IV pasal 7 ayat 2, menyatakan bahwa: "Orang tua dari anak usia wajib belajar berkewajiban memberikan pendidikan dasar kepada anaknya." 5 Selanjutnya pada bab VI pasal 28 ayat 5, menyatakan: "pendidikan anak usia dini pada jalur pendidikan informal berbentuk pendidikan keluarga atau pendidikan yang diselenggarakan oleh lingkungan".6

Masyarakat Desa Tambangan adalah salah satu desa dalam wilayah Kecamatan Kajang Kabupaten Bulukumba seluruhnya menganut agama Islam, yang tentunya setiap keluarga atau orang tua mempunyai kewajiban untuk mendidik anak-anaknya mengenai ajaran-ajaran Islam. Diketahui bahwa pendidikan Islam perlu ditanamkan kepada anak secara dini dalam 
rumah tangga. Namun, hal ini terkadang tidak dapat dilaksanakan dengan baik oleh orang tua karena beberapa faktor, antara lain; mungkin karena terlalu sibuk pada pekerjaannya sehingga tidak punya waktu mendidik anak-anaknya atau mungkin karena tidak memiliki pengetahuan yang cukup tentang agama maupun cara-cara mendidik anak.

Masyarakat desa Tambangan ini mayoritas sebagai petani. Pekerjaan itu dimulai dari pagi, siang, hingga sore hari dan tampaknya tidak punya waktu banyak untuk mendidik anak-anaknya. Idealnya, masyarakat Desa Tambangan sebagai penganut agama Islam dapat melaksanakan kewajibannya mendidik anak-anaknya di dalam rumah tangga mereka. Namun, terdapat berbagai faktor yang kemungkinan menyebabkan idealitas tersebut tidak sejalan dengan fakta empiris di lapangan. Realitas dan kemungkinan itulah yang menjadi motivasi bagi penulis untuk menguraikan persoalan dalam tulisan ini.

\section{RUANG LINGKUP PERMASALAHAN}

Berdasarkan uraian di atas, dapat dirumuskan permasalahan pokok sebagai berikut: "Bagaimana keterlibatan orang tua dalam pelaksanaan pendidikan agama Islam bagi anak dalam rumah tangga di Desa Tambangan Kecamatan Kajang Kabupaten Bulukumba?"

Ada beberapa sub masalah yang dapat di-breakdown dari permasalahan pokok di atas adalah:

1. Bagaimana keterlibatan orang tua dalam pendidikan agama Islam dalam rumah tangga di desa Tambangan?

2. Bagaimana cara orang tua melaksanakan pendidikan agama Islam bagi anak dalam rumah tangga di desa Tambangan?

Permasalahan yang muncul yang berkaitan dengan pelaksanaan pendidikan agama Islam bagi anak di rumah tangga sangat beragam. Oleh karena itu, dalam penelitian ini perlu dibatasi ruang lingkupnya sebagai berikut:

a. Keterlibatan orang tua dalam melaksanakan pendidikan agama Islam di rumah tangga, apakah oarang tua terlibat langsung atau tidak langsung.

b. Cara atau metode yang ditempuh orang tua dalam melaksanakan pendidikan agama Islam di rumah tangga.

\section{METODE PENELITIAN}

Pendekatan yang digunakan dalam penelitian ini adalah pendekatan multi disipliner, yaitu: 


\section{Pendekatan teologis-normatif}

Pendekatan teologis-normatif digunakan untuk mencari pembenaran dari suatu ajaran agama dalam rangka menemukan pemahaman atau pemikiran keagamaan yang dapat dipertanggungjawabkan secara normatif

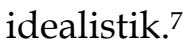

Pendekatan ini digunakan karena penelitian ini berkaitan dengan pelaksanaan pendidikan agama Islam di rumah tangga, tentunya hal ini akan dikaji berdasarkan ketentuan-ketentuan agama yang bersumber dari Alquran dan hadis-hadis Nabi.

\section{Pendekatan Pedagogis}

Pendekatan ini menggunakan teori-teori pendidikan dalam mengkaji data yang diperoleh di lapangan. Pelaksanaan pendidikan agama Islam di rumah tangga yang menjadi penelitian ini mempunyai kaitan yang erat dengan teori-teori pendidikan, khususnya tentang strategi dan metode pembelajaran yang digunakan orang tua selaku pendidik dalam berinteraksi dengan anaknya sebagai peserta didik.

\section{Sumber Data}

Sumber data yang dipilih adalah dari unsur pemerintah, tokoh agama, tokoh masyarakat, unsur petani dan unsur pegawai negeri sipil. Selain beberapa unsur di atas, sumber data lainnya adalah dokumen dan buku literatur yang ada hubungannya dengan masalah yang diteliti.

\section{Teknik dan Istrumen Pengumpulan Data}

Dalam mengumpulkan data, penulis melakukan, pertama, wawancara mendalam (in-depth interview). Kedua, observasi dan pengamatan tuntas. Ketiga, dokumentasi.

\section{Teknik Pengolahan Analisis Data}

Proses pengolahannya mengikuti teori Miles dan Huberman, sebagaimana dikutip oleh Sugiyono bahwa, "proses pengolahan data melalui tiga tahap, yaitu reduksi data penyajian data (data display) dan verifikasi/penarikan kesimpulan" ${ }^{8}$ Selanjutnya, data yang telah dikumpulkan dianalisis dengan teknik analisis induktif, yaitu data yang diperoleh/ditemukan di lapangan dianalisis kemudian menarik suatu kesimpulan. 


\section{KEHIDUPAN BERAGAMA MASYARAKAT DESA TAMBANGAN}

Kehidupan beragama yang dimaksud dalam pembahasan ini adalah aktivitas keseharian masyarakat Desa Tambangan yang erat kaitannya dengan ketaatan kepada ajaran agama dan pengabdian mereka kepada Allah swt. Agama yang dimaksud adalah agama Islam, karena satusatunya agama yang dianut oleh masyarakat adalah agama Islam.

Untuk mengetahui dengan jelas gambaran kehidupan beragama masyarakat Kajang, khususnya masyarakat Desa Tambangan saat ini, akan diuraikan dengan membatasi pada aspek-aspek:

- Aktivitas masyarakat yang berhubungan dengan ibadah kepada Allah Swt.

- Aktivitas masyarakat yang berbentuk acara-acara ritual keagamaan.

Penjelasan lebih lanjut dari aspek-aspek di atas adalah sebagai berikut:

\section{Aktivitas Masyarakat Yang Berhubungan Dengan Ibadah Kepada Allah} Swt.

\section{Pelaksanaan ibadah salat}

Salat sebagaimana kita ketahui hukumnya wajib bagi seluruh umat Islam yang sudah baligh, hal ini berdasarkan Q.S. al-Baqarah/2:43. Hukum wajibnya salat diyakini oleh seluruh masyarakat Desa Tambangan. Namun demikian, keyakinan tentang hukum wajibnya salat tidak diaktualisasikan secara baik oleh sebagian besar masyarakat dalam kehidupan sehari-hari. Berdasarkan informasi yang diperoleh dari beberapa informan mengatakan bahwa hanya sebagian kecil masyarakat melaksanakan salat wajib lima kali sehari semalam, dibuktikan dengan kehadiran mereka salat Jum'at di masjid. Jumlah penduduk laki-laki yang mukim di sekitar masjid jauh lebih banyak dibanding dengan yang hadir salat Jum'at di masjid, padahal mereka tidak punya halangan yang dapat dibenarkan oleh ajaran agama, bahkan mereka berada di rumah masing-masing pada saat salat Jum'at dilaksanakan. Di sisi lain, sebagian besar umat Islam tidak melaksanakan salat wajib kecuali salat Jum'at, salat sunat tarwih dan salat sunat Id (dua hari raya). Dikemukakan pula, bahwa orang tua yang tidak salat umumnya yang bermata pencaharian sebagai petani, alasannya mereka tidak tahu mengaji dan tidak menghafal bacaan-bacaan salat.

Dari beberapa keterangan di atas, dapat diambil suatu kesimpulan bahwa pelaksanaan salat bagi masyarakat Desa Tambangan terdapat tiga kelompok, yaitu:

1) Kelompok masyarakat yang melaksanakan salat lima waktu dengan baik. 
2) Kelompok masyarakat yang tidak melaksanakan salat sama sekali.

3) Kelompok masyarakat yang melaksanakan salat tertentu saja, misalnya salat Jum'at, salat sunat dua hari raya.

\section{Pelaksanaan ibadah puasa}

Ibadah puasa kedudukannya sama dengan ibadah salat, hukumnya wajib bagi umat Islam dan termasuk rukun Islam. Dasar hukum wajibnya ibadah puasa dijelaskan oleh Allah swt. dalam Q.S. al-Baqarah/2:183. Ayat ini mengandung makna bahwa setiap orang mukmin tidak boleh meninggalkan puasa, kecuali mempunyai alasan-alasan yang dibenarkan oleh syariat. Masyarakat Desa Tambangan sebagian besar sudah melaksanakan puasa pada bulan Ramadan sebulan penuh. Namun, salah satu dusun dalam wilayah Desa Tambangan masyarakatnya melaksanakan kewajiban puasa pada bulan Ramadan tidak sebulan penuh. Mereka hanya melaksanakan puasa 3 (tiga) hari pertama secara berturut-turut, 3 (tiga) hari pada pertengahan yakni pada hari kesebelas, kedua belas, dan ketiga belas, serta 3 (tiga) hari terakhir yakni pada hari kedua puluh tujuh, kedua puluh delapan, dan kedua puluh sembilan. Pada tiga hari terakhir tersebut, mereka juga membersihkan kuburan para leluhur dan diikuti dengan berdoa dengan menyiapkan makanan.

Pelaksanaan puasa seperti di atas, mereka yakini sama dengan berpuasa sebulan penuh. Selain itu masih terdapat sebagian masyarakat yang tidak berpuasa sama sekali.

Berdasarkan uraian di atas dapat disimpulkan bahwa masyarakat dalam menjalankan puasa Ramadan terdapat tiga kategori, yakni:

- Masyarakat yang melaksanakan puasa sebulan penuh

- Masyarakat yang tidak melaksanakan sebulan penuh

- Masyarakat yang tidak berpuasa sama sekali.

\section{Pelaksanaan zakat}

Zakat merupakan salah satu rukun Islam dan wajib ditunaikan oleh umat Islam yang memiliki kemampuan. Kewajiban tersebut didasarkan

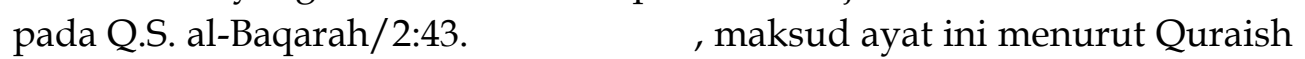
Shihab yakni tunaikan zakat dengan sempurna tanpa mengurangi dan menangguhkan serta sampaikan dengan baik kepada yang berhak menerimanya. ${ }^{9}$ Zakat meliputi, zakat harta dan zakat fitrah. Namun demikian zakat yang paling dikenal oleh masyarakat Desa Tambangan adalah zakat fitrah. Semua masyarakat yang memiliki kemampuan setiap tahunnya membayar zakat fitrah baik berupa uang maupun berupa bahan makanan sesuai dengan jumlah yang ditetapkan oleh Badan Amil Zakat 
kabupaten. Pembayaran zakat dikoordinir secara langsung oleh amil zakat yang dibentuk oleh pemerintah, sehingga masyarakat tidak mendapat peluang untuk membayar secara langsung ke yang berhak menerima zakat.

Adapun zakat harta (mal) tidak banyak dikenal oleh masyarakat, baik dari segi jenis dan jumlah harta yang dikenai zakat maupun dari segi jumlah yang harus dikeluarkan. Oleh karena itu, masyarakat yang membayar zakat harta sangat minim belum mencapai belasan orang. Zakat fitrah yang terkumpul dibagi dengan berpedoman kepada ketentuan yang ditetapkan oleh Amil zakat kabupaten, yaitu:

1) Untuk orang miskin sebanyak: $50 \%$

2) Untuk Amil sebanyak: $10 \%$

3) Untuk LPTQ tingkat kecamatan: $20 \%$

4) Untuk LPTQ tingkat kabupaten: $20 \%$

Dijumpai pula segelintir masyarakat yang membayar zakat fitrah dengan beras disertai dengan gula, garam, dan sayuran atas dasar keyakinan bahwa zakat ini nantinya menjadi bahan makanan di hari kemudian.

\section{Pelaksanaan haji}

Haji adalah kewajiban yang diperintahkan Allah swt., kepada setiap manusia yang mampu melaksanakannya, berdasarkan firman Allah Q.S. Ali Imran/3:97. Kewajiban tersebut dilaksanakan satu kali seumur hidup, yang kedua dan seterusnya hukumnya sunat. Penduduk Desa Tambangan yang mampu melaksanakan ibadah haji masih sangat terbatas, walaupun beberapa tahun terakhir setiap tahun ada yang melaksanakan ibadah haji. Sebagian dari mereka masih memerlukan pembinaan dalam hal antara lain kemampuan membaca Alquran, kesalehan individual dan sosial.10

\section{Aktivitas Masyarakat Yang Berbentuk Acara-acara Ritual Keagamaan}

Acara ritual keagamaan yang sering dilakukan oleh masyarakat dalam kehidupan sehari-hari dalam bahasa Konjo ${ }^{11}$ disebut $a^{\prime}$ baca barasanji dan $a^{\prime}$ baca doang, dalam bahasa Indonesia berarti membaca bersanji dan membaca do'a. Membaca barsanji dan membaca doa dilakukan pada kegiatan-kegiatan tertentu.

- Membaca barsanji dilaksanakan pada kegiatan/acara perkawinan, masuk rumah baru, aqiqah, khatam Quran, peringatan maulid Nabi di rumah, dan syukuran.

- Membaca doa dilaksanakan pada kegiatan/acara menyambut dan melepas bulan Ramadan, syukuran selesai panen, masuk rumah baru, aqiqah, khatam Quran dan perkawinan serta pada acara-acara kematian. 
Kegiatan membaca barsanji selalu diakhiri dengan a'baca doang (membaca doa), tetapi acara membaca doa tidak selalu didahului dengan membaca barsanji. Membaca barsanji diyakini oleh masyarakat akan mendatangkan keselamatan bagi mereka.

\section{Peran Orang Tua dalam Pelaksanaan Pendidikan Agama Islam}

Keterlibatan orang tua dalam pendidikan agama Islam dalam rumah tangga merupakan suatu tuntutan yang harus dijalankan. Sesuai dengan firman Allah dalam Q.S. al-Tahrim/66:6, ayat ini dapat dipahami bahwa salah satu amanah yang diberikan kepada orang tua adalah mendidik anak, selain tugas lainnya yaitu melindungi dan memeliharanya. Orang tua adalah sebagai pendidik di dalam keluarga, karena itu menurut al-Gazali sebagaimana yang dikutip oleh M. Arifin, bahwa orang tua terus melatih anak-anaknya kepada kebaikan, hati anak suci bagaikan mutiara cemerlang, bersih dari segala ukiran dan gambaran, ia dapat menerima segala yang diukirkan atasnya dan condong kepada segala yang dicondongkan kepadanya. Apabila anak dibiasakan dan diajar kebaikan jadilah ia baik dan berbahagia dunia akhirat, sedang orang tua dan pendidiknya turut mendapat bagian pahalanya. Tetapi apabila anak dibiasakan dan diajar kejelekan, maka celaka dan rusaklah ia sedang orang tua dan pendidiknya turut mendapat beban dosanya. ${ }^{12}$

Orang tua sebagai pembentuk dan pemimpin keluarga mempunyai kekuasaan pendidikan. Kekuasaan pendidikan dipergunakan untuk memelihara anak dan membimbingnya sampai anak menjadi manusia dewasa yang dapat hidup berdiri sendiri dan memiliki rasa tanggung jawab.

Keterlibatan orang tua dalam mendidik anak pada hekaketnya dimulai sejak anak dalam kandungan, sesudah lahir sampai dewasa.

Ibnul Djauzi dalam bukunya "al-Tib al-Ruhani", sebagaimana dikutip oleh Athiyah al-Abrasyi, mengatakan:

Pembentukan anak yang utama ialah di waktu kecil, apabila seorang anak dibiarkan melakukan sesuatu yang utama ialah di waktu kecil, apabila seorang anak dibiarkan melakukan sesuatu yang tidak baik dan menjadi kebiasaan baginya, maka sukar untuk diperbaiki. Artinya bahwa pendidikan budi pekerti yang mulia wajib dimulai di rumah, dalam keluarga, sejak kecil dan tidak membiarkannya tanpa pendidikan, bimbingan dan petunjuk dari orang tuanya. 13

Lingkungan rumah tangga menjadi lingkungan pertama anak dibesarkan dan dididik, memberikan peranan yang sangat berarti dalam proses pembinaan dan pendidikan, sebab lingkungan inilah untuk pertama kalinya anak menerima sejumlah nilai dan norma. Oleh karena itu, orang tua merupakan penanggung jawab terhadap pendidikan anaknya. ${ }^{14}$ 
Dari beberapa pendapat di atas dapat dipahami, bahwa peran serta orang tua dalam mendidik anak-anak mereka di rumah tangga sangat menentukan bagi pembentukan moral dan perilaku anak. Peran orang tua sebagai pendidik di rumah tak dapat digantikan oleh guru di sekolah. Karena itu, orang tua dituntut untuk terlibat secara langsung dalam mendidik anak-anaknya dan tidak menyerahkan sepenuhnya kepada guru di sekolah.

Secara umum, kondisi peran serta orang tua dalam pelaksanaan pendidikan agama terhadap anak-anak mereka adalah sebagai berikut:

a. Sebagian keluarga ada yang menaruh perhatian penuh atas pembinaan pendidikan agama putra-putri mereka. Bapak atau ibu memiliki kemampuan mengaji/membaca Alquran, namun tidak berani mengajari sendiri putra-putri mereka.

b. Sebagian keluarga ada yang acuh tak acuh dalam pembinaan pendidikan agama, mereka menyerahkan sepenuhnya kepada kemauan anak.

c. Sebagian keluarga ada yang menghalangi putra-putrinya mengikuti pendidikan agama di luar yang diwajibkan sekolah.

d. Sebagian keluarga ada yang memacu diri dan putra-putri mereka untuk memperdalam agama, karena mereka sadar akan kekurangan yang ada pada dirinya

Untuk mengetahui lebih jelas bagaimana kondisi peran serta orang tua dalam pelaksanaan pendidikan agama di rumah tangga di desa Tambangan, penulis melakukan wawancara dengan beberapa informan yang hasilnya dapat disimpulkan:

Bahwa tidak ada orang tua yang terlibat secara langsung mendidik anak-anak mereka tentang ajaran agama Islam, mereka menyerahkan sepenuhnya kepada sekolah, kecuali mengajar baca Alquran atau mengaji. Orang tua yang terlibat secara langsung mengajar mengaji anak-anak mereka sangat sedikit jumlahnya, justru banyak dijumpai anak-anak merekalah yang mengajar orang tuanya tentang cara-cara shalat, bacaanbacaannya, cara-cara berwudhu, dan lain-lain yang berkaitan dengan pengetahuan dasar tentang agama.

Dalam mengajarkan sopan santun dan sifat-sifat yang baik lainnya atau yang dikenal dengan pendidikan akhlak, seluruh orang tua terlibat. Seperti tidak boleh berbohong, tidak boleh berkelahi, sopan dalam bertamu, tidak ribut kalau ada orang berbicara dan sebagainya. Namun demikian pendidikan kesopanan dan sifat-sifat terpuji lainnya (akhlak) terhadap anak tidak sepenuhnya atas dasar perintah agama, tetapi atas dasar nilai-nilai dan norma-norma sosial yang harus diwariskan kepada anak-anak mereka. 


\section{Cara yang Ditempuh Orang Tua dalam Melaksanakan Pendidikan Agama Islam di Rumah Tangga}

Cara yang dimaksud dalam pembahasan ini adalah jalan atau teknik yang digunakan oleh orang tua dalam mendidik anak-anak mereka tentang ajaran agama Islam. Makin baik cara yang digunakan makin efektif pula pencapaian tujuan pendidikan.

Pada pembahasan yang lalu telah dikemukakan bahwa orang tua kebanyakan tidak terlibat secara langsung mengajarkan pendidikan agama Islam kepada anak-anak mereka, tetapi menyerahkan kepada guru agama di sekolah, di masjid, dan TKA/TPA, terutama masalah yang terkait dengan pengetahuan tentang keimanan dan ibadah seperti; rukun-rukun iman, sifat-sifat Tuhan, nama-nama Tuhan selain Allah (asmā' al-husnā), thaharah wudhu, tayamum, rukun Islam dan masalah-masalah yang terkait dengannya, dan lain-lain sebagainya. Keterlibatan orang tua dalam mendidik anak-anaknya lebih banyak pada bidang pendidikan moral, sopan santun atau akhlak. Karena itu, cara yang ditempuh orang tua dalam mendidik anak yang dikemukakan pada uraian ini lebih banyak terkait dengan pendidikan akhlak. Namun demikian, tidak berarti meninggalkan sama sekali masalah pendidikan keimanan dan ibadah. Adapun cara-cara yang ditempuh orang tua dalam mendidik anak-anak mereka adalah sebagai berikut:

\section{Membacakan adzan dan iqamat bagi anak yang baru lahir}

Bagi anak yang baru lahir, disyariatkan oleh Islam untuk menyuarakan adzan di telinga kanan dan qamat di telinga kiri. Cara ini menurut responden, masih sedikit sekali orang tua yang melakukannya dan caranyapun berbeda dengan tuntunan syariat Islam, yaitu menyuarakan adzan di telinga anak laki-laki dan qamat di telinga anak perempuan. Ketika ditanyakan apa makna yang terkandung dalam menyuarakan adzan dan qamat di telinga anak yang baru lahir, ia menjawab supaya nama Allah pertama masuk di telinga anak dan jauh dari setan.

\section{Membiasakan anak melakukan yang baik}

Untuk mendidik anak menjadi manusia yang memiliki sifat-sifat yang mulia dan terhindar dari sifat-sifat yang buruk bukanlah sesuatu yang mudah tetapi memerlukan waktu yang lama dan membiasakannya sejak kecil.

Membiasakan anak berbuat baik sejak kecil sudah dilakukan oleh para orang tua di Desa Tambangan sesuai dengan apa yang dikemukakan oleh responden, bahwa: "anak-anak sejak kecil sudah dibiasakan berbuat 
dan berbicara dengan baik, seperti; kalau lewat didepan orang tua ucapkan "tabe" (permisi), menghormati tamu, tidak berkelahi, tidak ribut kalau ada orang sedang berbicara, kalau bertamu ke rumah orang lain duduk dulu baru berbicara, membantu orang tua, tidak berdusta, tidak memaki, tidak berkata-kata kotor.

Hasil wawancara di atas menunjukkan bahwa, pembiasaan yang dilakukan oleh orang tua berkaitan dengan pendidikan akhlak. Mengenai masalah ibadah, tidak semua orang tua membiasakan anak mereka untuk beribadah (salat dan puasa), karena mereka sendiri kebanyakan tidak melakukan salat lima waktu dan tidak berpuasa pada bulan Ramadan. Adapun orang tua yang membiasakan anaknya melakukan salat caranya adalah selalu memperingatkan anaknya setiap waktu salat.

\section{Memberi Nasehat}

Memberi nasehat kepada anak sangat penting dilakukan oleh orang tua, baik nasehat itu sifatnya preventif yakni nasehat yang bertujuan agar anak selalu berbuat baik dan tidak melakukan perbuatan-perbuatan jahat, maupun nasehat yang sifatnya represif atau korektif, yakni nasehat yang bertujuan agar anak kembali sadar dari perbuatan jahat yang pernah dilakukannya dan sekaligus memberikan apresiasi atas perbuatan baik yang dilakukannya. Pemberian nasehat kepada anak telah dicontohkan oleh Lukman al-Hakim dalam Q.S. Lukman/31: 13-19.

Pemberian nasehat dilakukan oleh orang tua di Desa Tambangan terus menerus agar anak mereka melakukan hal-hal yang terpuji dan meninggalkan hal-hal yang terpuji dan meninggalkan hal-hal yang buruk, seperti menasehati anak untuk tidak nakal, tidak berdusta, tidak mencuri , tidak bergaul dengan anak-anak nakal dan sekaligus menjelaskan akibatakibat yang timbul dari berbuat baik dan berbuat jahat.

\section{Pemberian Contoh Teladan}

Pemberian contoh teladan oleh orang tua kepada anak sangat penting karena anak akan meniru apa yang dilakukan orang tuanya. Contoh jika orang tua merokok anaknya juga merokok, orang tuanya tidak salat anaknya juga tidak salat dan seterusnya.

Zakiah Daradjat, mengatakan bahwa:

Penampilan, perkataan, akhlak dan apa saja yang terdapat pada pendidik (termasuk orang tua) dilihat, didengar dan diketahui oleh para anak didik, akan mereka serap dan tiru, serta lebih jauh akan mempengaruhi pembentukan dan pembinaan akhlak mereka. ${ }^{15}$ 
Semua penampilan orang tua (ibu dan bapak) dalam kehidupan sehari-hari yang disaksikan dan dialami oleh anak akan ditirunya, baik berupa ucapan maupun perbuatan. Karena itu, orang tua terutama ibu harus senantiasa memperdengarkan kata-kata yang baik (tayyibah) dan contoh perbuatan yang baik sesuai dengan ajaran-ajaran agama Islam, misalnya mengerjakan salat, memberikan sedekah, membaca doa bila memulai dan sesudah makan, hendak tidur dan bangun tidur dan sebagainya.

Pergaulan anak dengan orang tua mempunyai dampak yang sangat besar terhadap pembentukan kepribadian anak. Hurlock, sebagaimana dikutip oleh HM. Arifin mengatakan:

Sikap dan tingkah laku anak tampak jelas sekali dipengaruhi oleh keluarga dimana ia dilahirkan dan berkembang. Rumah adalah lingkungan pertama bagi anak, keluarga memberi percontohan sikap anak terhadap orang lain. Anak menjadikan orang tuanya sebagai model dari penyesuaian dirinya dengan kehidupan. Selanjutnya Hurlock mengatakan bahwa percontohan yang fundamental yang terbentuk dalam rumah tidak dapat diberantas sampai ke akar-akarnya, hanya dapat dihambat bila telah menjadi besar. ${ }^{16}$

Pemberian contoh teladan yang dilakukan oleh orang tua di Desa Tambangan ada dua bentuk, yakni:

1) Contoh teladan yang baik sesuai dengan nilai-nilai ajaran Islam dalam hal keimanan/akidah, ibadah, dan akhlak.

2) Contoh teladan yang tidak baik, seperti dalam masalah aqidah orang tua sering melakukan hal-hal yang condong kepada kemusyrikan, dalam masalah ibadah orang tua tidak salat dan tidak berpuasa pada bulan Ramadan, dalam masalah akhlak orang tua sering cekcok dengan tetangga, memutus hubungan persaudaraan, tidak jujur dan sebagainya. ${ }^{17}$

\section{Perintah dan larangan}

Kalau disimak dengan baik kandungan Alquran, maka didalamnya akan ditemukan banyak perintah yang harus dilaksanakan dan banyak larangan yang harus ditinggalkan oleh manusia sebagai hamba Allah swt. Salah satu contoh perintah Allah adalah perintah untuk menyembah Dia, Q.S. al-Baqarah/2: 21.

Adapun contoh larangan Allah swt. diantaranya adalah Q.S alHujurāt/49: 11. Semua perintah dan larangan Allah swt., tujuannya adalah untuk menjadikan manusia bertaqwa dan meraih keselamatan dunia dan akhirat. Demikian pula halnya perintah dan larangan yang diterapkan oleh orang tua kepada anak-anak mereka, agar mereka menjadi anak yang baik, hidup sejahtera dan bahagia di dunia ini. Contoh; perintah untuk rajin sekolah, pergi mengaji, shalat menerima pemberian dengan tangan kanan disertai ucapan terima kasih dan lain-lain. Larangan berdusta, berkelahi, 
mengganggu teman, mencuri, lalu lalang di depan tamu, larangan bermalas-malasan dan sebagainya.

Larangan orang tua seringkali disampaikan kepada anak-anaknya dengan kalimat yang tidak langsung menunjuk kepada maksud larangan tersebut, tetapi dalam bentuk simbol atau perumpamaan, seperti yang dicontohkan oleh Mappidaya:

Jako patungkuli areng, artinya jangan bertopang dagu. Bertopang dagu adalah simbol kemalasan. Jadi kalimat tersebut bermakna larangan bermalasmalasan. Untuk mempertegas agar larangan itu diindahkan, biasanya diikuti dengan ancaman tentang akibat dari larangan tersebut, seperti. Jako tinro eleki garringako, artinya jangan tidur pagi nanti sakit. Maksudnya kalau tidur pagi berarti orang tersebut malas bekerja untuk mencari nafkah dan rezkipun tidak bisa diperoleh. ${ }^{18}$

\section{Metode tradisional}

Orang tua yang mengajar membaca Alquran secara langsung di rumah menggunakan metode tradisional atau dikenal dengan metode alBagdadi. Cara penerapan metode ini, yakni memulai dengan memperkenalkan huruf-huruf hijaiyah, membaca huruf-huruf hijaiyah sesuai dengan barisnya (Fathah, Fathatain, kasrah, kasratain, damma, dammatain, dan sukun) dan memperkenalkan tanda-tanda baca lainnya. Seterusnya membaca kata bersambung dua, tiga atau lebih huruf hijaiyah sampai akhirnya dilatih membaca surah-surah pendek dalam juz Amma sampai tamat. Metode tradisional ini membutuhkan waktu berbulan-bulan, bahkan sampai satu tahun atau lebih dan dalam satu angkatan paling banyak bisa diajar 5 orang murid. Apa yang diuraikan di atas didasarkan pada hasil observasi yang dilakukan pada bulan Februari 2010.

\section{SIMPULAN}

Keterlibatan orang tua di Desa Tambangan dalam melaksanakan pendidikan agama Islam di rumah tangga ada dua bentuk, yakni:

a. Terlibat secara langsung, berinteraksi secara edukatif antara pendidik (orang tua) dengan peserta didik (anak). Keterlibatan secara langsung lebih fokus pada aspek pendidikan moral, pembentukan akhlak dan pendidikan baca Alquran. Orang tua yang terlibat langsung dalam pendidikan baca Alquran jumlahnya terbatas dan masih menggunakan metode tradisional.

b. Tidak terlibat secara langsung. Orang tua menyerahkan kepada guru agama di sekolah, TKA dan TPA. Orang tua menganggap guru-guru agamalah yang memiliki kemampuan untuk mengajarkan pengetahuan 
agama yang lebih komprehensif kepada anak-anak mereka. Keterlibatan orang tua sebatas pemberian motivasi dan dukungan finansial.

Cara atau metode yang digunakan orang tua di Desa Tambangan dalam melaksanakan pendidikan agama Islam lebih diarahkan kepada pemberian contoh teladan, nasehat, pembiasaan, perintah dan larangan. Nampaknya metode ini digunakan disesuaikan dengan materi dan tujuan pendidikan agama Islam yang menjadi fokus perhatian para orang tua.

\section{CATATAN AKHIR}

1. Imam Bukhāri, Saḩih al-Bukhāry, Juz 1, Beirut Libanon: Dār al-Kutub al-Ilmiyah, t.th.), h. 421.

2. Departemen Agama RI, Al-Qur'an dan Terjemahnya, Mujamma' al-Malik Fahd li Tiba'at al-Mushhaf al-Syarīf Madīnah al-Munawwarah Kerajaan Arab Saudi, 1418 H, h. 951.

3. Abdullah Nashih Ulwan, Tarbiyah al-Aulād Fi al-Islām, terj. Saifullah Kamalie dan Hery Noer Ali, Pedoman Pendidikan Anak dalam Islam, Jilid I, Semarang: Asy-Syifa, t.th, h. 159.

4. Lihat Baihaqi A.K., Mendidik Anak dalam Kandungan menurut Ajaran Pedagogis Islami, cet. II, Jakarta: Darul Ulum Press, 2001, h. 46.

5. Republik Indonesia, Undang-Undang RI N0. 20 Tahun 2003 tentang Sistem Pendidikan Nasional, cet I, Jakarta: Sinar Grafika, 2003, h. 7.

6. Ibid., h.15.

7. Lihat Imam Suprayogo dan Tabrani, Metodologi Penelitian Sosial-Agama, Bandung: Remaja Rosdakarya, 2001, h. 59.

8. Lihat Sugiyono, Metode Penelitian Pendidikan Pendekatan Kuantitatif, Kualitatif dan $R$ \& D, cet. VI, Bandung: Alfabet, 2008, h. 336-345.

9. M. Quraish Shihab, Tafsir al-Mishbah, Vol I, cet. VIII, Jakarta: Lentera Hati, 2006, h. 176.

10. Arifin H. Tokoh Agama/Kepala MTs, Wawancara, tgl. 8 Februari 2010

11. Bahasa Konjo adalah bahasa yang digunakan oleh masyarakat Kecamatan Kajang dan sekitarnya serta sebagian masyarakat Kabupaten Sinjai bagian Barat dalam berkomunikasi. Bahasa Konjo memiliki banyak kesamaan dengan bahasa Makassar dan bahasa Bugis.

12. Lihat M. Arifin, Hubungan Timbal Balik Pendidikan Agama di Lingkungan Sekolah dan Keluarga, cet.IV, Jakarta: Bulan Bintang, 1978, h. 80.

13. Lihat Ibid.

14. Lihat Abd. Aziz Shalih dan Abd. Aziz al-Majid, Tarbiyah wa Thurūq al-Tadrīs, Jus I, Mesir: Dār al-Ma'ārif, t.th., h. 2.

15. Lihat Zakiah Daradjat, Pendidikan Islam dalam Keluarga dan Sekolah, cet. III; Jakarta: CV. Ruhama, 1995, h. 72.

16. M. Arifin, op. cit., h.92.

17. Rajamuddin, Pengurus Masjid, Wawancara, tgl. 9 Februari 2010.

18. Mappidaya, Tokoh Masyarakat/Guru SD, Wawancara, tgl. 11 Februari 2010. 


\section{DAFTAR PUSTAKA}

A. K., Baihaqi, Mendidik Anak dalam Kandungan Menurut Ajaran Pedagogis Islami, cet. II, Jakarta: Darul Ulum Press, 2001.

Arifin, H.M., Filsafah Pendidikan Islam, cet. I, Jakarta: Bina Aksara, 1987.

Bukhāri, Imam, Shahih al-Bukhāriy, Juz 1, Beirut Libanon, Dār al-Kutub al'Ilmiyyah, t.th.

Daradjat, Zakiah, Pendidikan Islam dalam Keluarga dan Sekolah. Cet. III; Jakarta: CV. Ruhama, 1995.

Departemen Agama R.I., Al-Qur'an dan Terjemahnya, Mujamma' al-Mālik Fahd li Thiba'at al-Mushhaf al-Syarif Madinah al-Munawwarah Kerajaan Arab Saudi, $1418 \mathrm{H}$.

Republik Indonesia, Undang-undang RI. Nomor 20 Tahun 2003 Tentang Sistem Pendidikan Nasional, cet. I, Jakarta: Sinar Grafika, 2003.

Shalih, Abd. Aziz, dan Abd Aziz al-Majid, al-Tarbiyah wa Thurūq al-Tadrīs, Juz I, Mesir Dār al-Ma'arif, t.th.

Shihab, M. Quraish, Membumikan Al-Qur'an, cet. I, Bandung: Mizan, 1992.

Sugiyono, Metode Penelitian Pendidikan Pendekatan Kuantitatif, Kualitatif dan R \& D, cet. VI, Bandung: Alfabet, 2008.

Suprayogo, Imam dan Tobroni, Metodologi Penelitian Sosial Agama, Bandung: Remaja Rosdakarya, 2001.

Ulwan, Abdullah Nashih, al-Tarbiyah al-Aulād fi al-Islām, terj. Saifullah Kamalie dan Hery Noer Ali, Pedoman Pendidikan Anak Dalam Islam, Jilid I, Cet. III, Semarang: Asy-Syifa', 1981. 